Interpretations of Law and Ethics in Muslim Contexts 


\section{Muslim Civilisations Abstracts \\ Series Editor: Aptin Khanbaghi}

Books in the series include:

Encyclopedias about Muslim Civilisations

Interpretations of Law and Ethics in Muslim Contexts

Cities: Two Centuries of Scholarship from Muslim Contexts

www.euppublishing.com/series.mca 


\title{
Interpretations of Law and Ethics in Muslim Contexts
}

\author{
Edited by
}

Aptin Khanbaghi

EDINBURGH

University Press

IN ASSOCIATION WITH

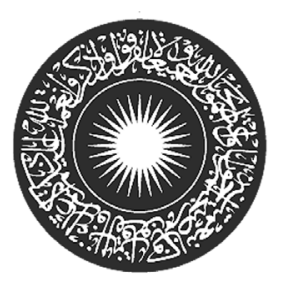

\section{THE AGA KHAN UNIVERSITY}

Institute for the Study of Muslim Civilisations 
The opinions expressed in this volume are those of the authors and do not necessarily reflect those of the Aga Khan University, Institute for the Study of Muslim Civilisations.

(C) Editorial matter and organisation Aptin Khanbaghi, 2012

(C) The abstracts, their several authors, 2012

Edinburgh University Press Ltd

22 George Square, Edinburgh EH8 9LF

www.euppublishing.com

Typeset in 10/12 Times New Roman by

Servis Filmsetting Ltd, Stockport, Cheshire, and

printed and bound in Great Britain by

CPI Group (UK) Ltd, Croydon CR0 4YY

A CIP record for this book is available from the British Library

ISBN 9780748645008 (hardback)

The right of the contributors to be identified as authors of this work has been asserted in accordance with the Copyright, Designs and Patents Act 1988. 